\title{
In-demand Soft Skills and Employability during and Post COVID-19: Evidence from EFL Teachers
}

\author{
Ahmad A.S. Tabieh ${ }^{1}$, Hiba Y Abuzagha ${ }^{2}$, Kazim A. Al Ghou ${ }^{3}$ \\ ${ }^{1-3}$ Middle East University, Jordan
}

\begin{abstract}
The Interest in blending soft skills along with the cognitive ones in the EFL teaching field originates from dimensioning the drastic changes facing the world with the hit of the COVID-19. Eventually, EFL teachers are confronted with hostile situations that challenge individuals' ability to adapt to the work environment. Employers and teachers in this particular field need to recognize this reality because they should be prepared to transform the classical approaches of education and respond by teaching strategies to mitigate these difficulties. Through the quantitative method, a questionnaire and a survey that 121 experienced employers and 250 teachers have responded to, this paper provides EFL teachers with a clear perception about their required soft skills acquisition degrees that are demanded by employers in the EFL teaching field. The results showed a strong availability degree in Communication and Time management. It also showed a significantly positive correlation between the acquisition of the in-demand soft skills and the EFL teachers' performance. Moreover, this paper contributes in providing employers some practical strategies and tools to be utilized to enhance their EFL teachers' soft skills acquisition, thus, enhancing the teaching-learning process.
\end{abstract}

Keywords: COVID-19, EFL teachers, Employability, Soft Skills.

\section{INTRODUCTION}

The field of language acquisition and teaching has witnessed several controversial debates about the skills set required for success. The skills that EFL teachers are demanded to possess to guarantee sufficient teaching-learning process are currently beyond the cognitive ones; soft skills that allow teachers to better deliver the content and effectively develop teaching strategies and assessment tools. In addition, these non-cognitive skills contribute to the improvement of the teaching-learning environment as they enable both teachers and students to interact and to practice the language teachinglearning process in its best level.

According to (Tseng, 2019; Garcia, 2014) Soft Skills, also known as Non-Cognitive Skills, are a mixture of emotions, attitudes, behavior and thoughts that are recognized by society and developed throughout individuals' attempts to determine values. Soft Skills can comprise personal characteristics, motivations, and attitudes and are very important for the employability and adaptability of EFL teachers, such as critical thinking skills, problem-solving skills, social skills, persistence, creativity, and self-control-that allow individuals to contribute meaningfully to society and to succeed in their public lives, workplaces, homes, and other societal contexts.

As for EFL teachers in particular, the top ten in-demand soft skills listed in(Cornali, 2018; Jaser Khalaf Mahasneh, 2016; Pisoni et al., 2019) are considered to be the success formula for EFL teachers to excel and to be highly employable in educational workplaces. The top ten soft skills are Being professionally ethical, Teamwork, Communication, Adaptability to change, Creativity, Innovation, Self-management, Flexibility, Time management and Critical thinking. These soft skills have created a solid foundation for implementing new methods of teaching and learning EFL; such as the Project-based learning which is currently gaining growing acceptance as an effective pedagogical approach in teaching languages. PBL requires both parties, learners and teachers, to be able to develop their abilities to cooperate through effective communication. Furthermore, they need to enhance their critical thinking skills in a step towards solving problems and being able to adapt to the change from teacher-centered class to the studentcentered ones (Robertson \& Adamson, 2020).

According to employers, EFL teachers need to embrace the amalgam between the two sets of skills; soft and academic, to facilitate the work process, especially during tough times like the COVID-19 crisis which has changed the teaching-learning environment (Singh Dubey \& Tiwari, 2020).

Unfortunately, the shift towards the online teachinglearning came with several constraints of human resources such as; low motivation of students in interacting with the online classes, poor time management, students lack of

Corresponding Author e-mail: atabieh@meu.edu.jo https://orcid.org/0000-0001-6762-6313

How to cite this article: Tabieh AAS, Abuzagha HY, Al Ghou KA (2021). In-demand Soft Skills and Employability during and Post COVID-19: Evidence from EFL Teachers. Pegem Journal of Education and Instruction, Vol. 11, No. 4, 2021, 219-229

Source of support: Nil

Conflict of interest: None.

DOI: $10.47750 /$ pegegog.11.04.21

Received: 10.06 .2021

Accepted: 31.08.2021 Publication: 01.10.2021 
discipline (Editor \& Medriano, 2021) and lack of flexibility in managing the teaching learning process. Also, the lack of selfmanagement among teachers and their resistance to change made them give up easily, as a result, their employability status was unstable and led to many of them losing their jobs.

Patel and Rietveld (2020) state that employment rates at educational workplaces are in drastic decline caused by the world's pandemic COVID-19, and employers have to make tough decisions regarding whom to fire or keep. Thus, preferences will be in favor of those teachers who possess the required set of soft skills, with the desired level, that enables them to succeed and contribute to the survival of the academic institution (Singh et al., 2014), especially during the world pandemic which imposed the shift to the online teaching and learning platforms (Mishra et al., 2020) .

Therefore, it is crucial for teachers to evaluate the acquisition of soft skills and to be given genuine feedback about the correlation between soft skills and EFL teachers' performance in educational workplaces from the perspective of employers themselves, which is the primary purpose of this paper. Basically, this paper introduces soft skills as a formula to obtain success in the educational filed; the acquisition of in-demand soft skills to maintain employability stability and to ensure effective EFL learning.

\section{Literature Review}

In the study conducted by Fixsen and Ridge (2019), the researchers examine results from an ethnography of SSPs in a university setting, using dramaturgical theory to investigate their cultural forms and ethos.

They begin by investigation the origins of the term 'Soft Skills" in the contemporary context and its relevance in the Higher Education sector. The focus here is on the resources of work stress and pressures on the staff within an organization that leads to selfdetermining, in addition to the focus on the cultural and social impact of SSPs while transforming the learning environment to the virtual platforms rapidly. This matter is considered as important as learning and developing professionals and academics with an interest in organizational practices.

Empirical research was conducted over almost two years in a UK university. Establishing professional and trusting relationships with managers in HR and organizational development was important to ease gaining information and access the parts of the organization that could not be, in normal situation, accessible. Another consideration was choosing from a variety of soft skills programs (SSPs) and activities available at the time, in addition to the list of courses and workshops suggested by Human Resources, to ensure preparing staff for a restructuring of the academic program.

The researchers interviewed stakeholders and managed to record their discussions manually in addition to the notes obtained through observations. The notes led to presenting inconsistency due to the gender imbalances. The researchers also noted that there was a discrepancy between the attempts to create positive atmosphere by managers and the reality of having overwhelming workload the staff has to handle.

Another study conducted by (Immanuel et al., 2021) (Rao, 2019) focuses on the significance of intrapersonal and soft skills in English language teaching. This paper presents the set of skills and the tool to use the person's knowledge in acquiring capacity to perform and execute. Acquiring skills is a must to succeed, yet, it can be challenging and taxing. The interpersonal skills highlighted in this study include Selfimprovement and emotional intelligence, which are considered essential for a healthy and effective communication among teachers and learners.

According to Harvard survey included in this study, a successful graduate will possess a ratio of 80:20 skills. $80 \%$ of the skills are emotional or social intelligences and $20 \%$ of academic intelligence. Based on this study which sheds the light on the importance of the interpersonal and soft skills, the researcher worked on identifying means and methods to teach these skills in English classrooms at the college level which in turn benefits the students in their career and social life.

The research method applied in this study is survey that was conducted among three categories; college students, graduates and hired-graduates. About 50 students responded to the survey and the data was collected. Additionally, a questionnaire was developed regarding the importance of interpersonal skills was used for all the three categories.

The results of the study presented some important areas in building interpersonal skills like the personal growth and maintaining social harmony. These two areas are essential parts of the students' life and career, and English classrooms are suitable arenas for teaching and developing these skills through effective communication. The main role of the English language teachers is in creating awareness among students of the importance of these skills and providing them with what they need to acquire them in the educational environment. It is worth to mention that the English teacher is vested with responsibility to finding the means and methods of integrating these skills in the English teaching environment and to enhance students' practice.

\section{Research Questions}

1. What is the degree of soft skills acquisition by the newlyhired EFL teachers in the educational workplaces from the employers' perspectives?

2. What is the relationship between the level of performance among the newly-hired EFL teachers and the in-demand soft skills which employers seek in the EFL teaching field?

3. Are there any significant statistical differences in the degree of soft skills acquisition attributed to the performance level of the newly-hired EFL teachers? 


\section{Methodology}

\section{Research Design}

The study is using a quantitative approach design

\begin{tabular}{lll} 
Descriptive & Correlational & Differences \\
\hline The degree of In- & The In-Demand soft & The difference in \\
$\begin{array}{l}\text { Demand soft skills } \\
\text { acquisition }\end{array}$ & $\begin{array}{l}\text { skills and newly- } \\
\text { hired graduates' } \\
\text { performance }\end{array}$ & $\begin{array}{l}\text { the in-demand soft } \\
\text { skills according } \\
\text { to the newly- } \\
\text { hired graduates } \\
\text { performance }\end{array}$ \\
& & \\
\end{tabular}

\section{Population and Sampling}

The study population consists of two groups; the first group is the administrative and managerial staff whose experience is over ten years in educational workplaces (Private Schools) in the capital city of Amman. The second group is the teaching staff (EFL teachers) who are newly-hired with one year of experience in the educational field (Private schools) in Amman. The sample has been chosen according to the convenience sampling and consisted of 121 members of the administrative staff and 250 teachers. The sample has been distributed according to gender, job title, and professional specialty.

\section{Research Instruments}

The instrument in this study is a questionnaire about the degree of awareness and the acquisition of soft skills by the newly-hired graduates. To answer the questions (1-5), the researcher has composed a Five-Likert questionnaire that includes a group of soft skills that have been detected throughout the literature review.

\section{Validity and Reliability of the Research Instruments}

The validity and reliability of the instrument, which is a questionnaire, to detect the degree of awareness and the acquisition of the in-demand soft skills by the newly-hired graduates.

The validity of the instrument has been checked using content validity method by presenting it to ten experts in the educational leadership in Jordanian universities and their comments and notes have been taken into consideration for improvements and amendments.

Moreover, the instrument has been applied to a pilot sample of 30 EFL teachers and administrators from outside the sample to rationing the study instrument and to check its validity to the application on the original sample group. The values of the specific correlation parameters have been calculated for the constructive validity check. As for the

Table 1. Correlation coefficient and Cronbach's Alpha of soft skills

\begin{tabular}{|c|c|c|c|}
\hline \multirow[b]{2}{*}{ Creative Thinking Skill } & \multicolumn{2}{|c|}{ Validity } & \multirow{2}{*}{$\begin{array}{l}\text { Reliability } \\
\text { Cronbach's Alpha }\end{array}$} \\
\hline & Pearson Correlation & Sig & \\
\hline Global Awareness & 0.82 & $0.000^{\star}$ & 0.91 \\
\hline Teamwork & 0.77 & $0.001^{*}$ & 0.81 \\
\hline Problem solving & 0.74 & $0.000^{*}$ & 0.85 \\
\hline Communication & 0.78 & $0.000^{*}$ & 0.86 \\
\hline Being Professionally Ethical & 0.70 & $0.03^{*}$ & 0.77 \\
\hline Time Management & 0.96 & $0.04^{*}$ & 0.78 \\
\hline Adaptability to change & 0.66 & $0.002^{*}$ & 0.88 \\
\hline Creativity & 0.79 & $0.000^{*}$ & 0.80 \\
\hline Self-Management & 0.77 & $0.000^{*}$ & 0.81 \\
\hline Innovation & 0.74 & $0.000^{*}$ & 0.85 \\
\hline Critical Thinking & 0.54 & $0.01^{\star}$ & 0.92 \\
\hline Self-Learning & 0.78 & $0.000^{*}$ & 0.78 \\
\hline Flexibility & 0.77 & $0.000^{\star}$ & 0.81 \\
\hline Decision Making & 0.91 & $0.000^{*}$ & 0.71 \\
\hline Leadership & 0.82 & $0.000^{*}$ & 0.89 \\
\hline Digital Literacy & 0.80 & $0.000^{*}$ & 0.90 \\
\hline
\end{tabular}


reliability of the instrument, it has been verified through Alpha Cronbach to measure the internal consistency. Table (1) show the Correlation coefficient and Cronbach's Alpha of soft skills.

\section{Data Analysis (Processing Data)}

1) Arithmetic means and standard deviations to calculate the degree of soft skills acquisition.

2) Pearson correlation coefficients to calculate the relationship between soft skills acquisition and the performance of the newly-hired graduates.

3) T-test to calculate the effect of the in-demand soft skills acquisition on the performance of the newly hired graduates.

The criterion adopted to measure the degree of soft skills acquisition by the newly hired graduates in the educational workplaces from the employers' perspectives

\begin{tabular}{lll}
\hline Interval & Relative Wight & Availability Degree \\
\hline $1-1.80$ & $20 \%-36 \%$ & Strongly Unavailable \\
$1.81-2.60$ & More than $36 \%-52 \%$ & Unavailable \\
$2.61-3.40$ & More than $52 \%-68 \%$ & Natural \\
$3.41-4.20$ & More than $68 \%-84 \%$ & Available \\
$4.21-5$ & More than $84 \%-100 \%$ & Strongly Available \\
\hline
\end{tabular}

\section{Procedures}

1. The researcher has collected and presented the literature review.

2. A questionnaire was composed.

3. Checking the validity and reliability of the research instruments.

4. Applying the instruments in the field, collecting data, coding it, and then processing it.

5. Doing the statistical analysis and processing the data by using the SPSS.

6. Coming up with the results of the study.

7. Discussing the results and writing recommendations.

\section{Findings / Results}

The finding of the degree of soft skills acquisition by the newly hired graduates in the educational workplaces from the employers' perspectives

Table 1. shows that the acquisition degree of Time Management/Organization and Communication was the highest among the other soft skills with arithmetic average of 4.91 and 4.52 respectively. On the other hand, Teamwork, Innovation and Self-management were available with arithmetic averages of 4.04, 3.73 and 3.44.

Employers have given a neutral degree of acquisition of skills like Adaptability to change, Being professionally ethical, Flexibility and Critical Thinking with arithmetic averages of $3.14,3.13,3.01$ and 2.91. In regards to the skill of Creativity, the acquisition degree's arithmetic average was 2.53 , which suggests the lack of this skill in the majority of EFL teachers in the educational workplaces from the employers' perspective.

The finding of the relationship between the level of performance among the newly hired graduates and the in-demand soft skills which employers seek in EFL teachers in the educational field.

The diagram reflects the importance of Being Professionally ethical to employers who gave this skill the first rank of importance. Figure 3 presents that $98 \%$ of employers in the educational workplaces see that the majority of the newly-hired graduates whose performance level is high and satisfactory possess the skill of Being professionally ethical while $2 \%$ of them see that they do not. Meanwhile, the EFL teachers whose performance is unsatisfactory were found to be lacking this skill according to $82 \%$ of employers while only $4 \%$ of them see that these EFL teachers do possess it.

The majority of respondents requested high acquisition of this particular skill in their EFL teachers and considered it as an essential and in-demand soft skills in their EFL teachers. It shows from the contrast that few employers considered it as less important. Though, it is placed in the requested points by all respondents.

Table 1: The Degree of Soft Skills Acquisition by the Newly Hired EFL Teachers from the Employers' Perspectives

\begin{tabular}{lllll}
\hline & $N$ & Mean & Std. Deviation & Availability Degree \\
\hline Being professionally ethical & 121 & 3.13 & .340 & Neutral \\
Communication & 121 & 4.52 & .44085 & Strongly Available \\
Self-management/ Discipline/ Stress management & 121 & 3.44 & .50837 & Available \\
Adaptability to Change & 121 & 3.1488 & .48151 & Neutral \\
Teamwork & 121 & 4.0405 & .54092 & Available \\
Critical Thinking & 121 & 2.9091 & .62249 & Neutral \\
Creativity & 121 & 2.5347 & .62044 & Unavailable \\
Innovation & 121 & 3.7397 & .65542 & Available \\
Time Management/ Organization & 121 & 4.9124 & .55326 & Strongly Available \\
Flexibility & 121 & 3.0124 & .59324 & Neutral \\
\hline
\end{tabular}




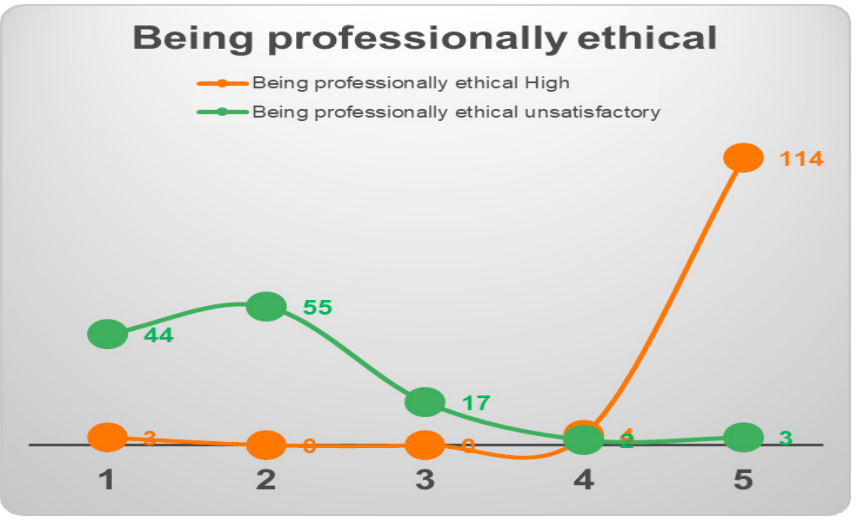

Figure 1: The Degree of Availability of Being Professionally Ethical in EFL Teachers

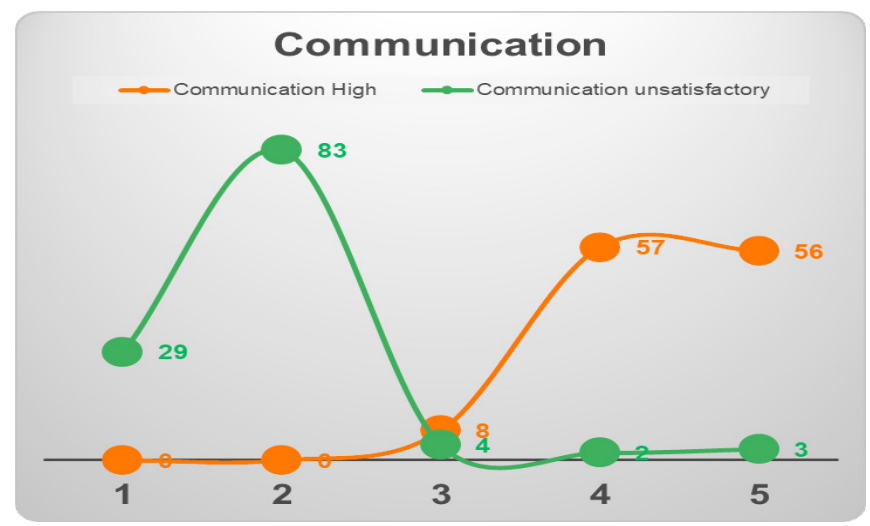

Figure 2. The Degree of Availability of Communication in EFL Teachers

As for Communication, the respondents reflected the importance of this skill acquisition during COVID-19. Figure 2 shows that $93 \%$ of employers see that EFL teachers with high performance level possess the required communication skill $\mathrm{w}$ $7 \%$ of them see that those EFL teachers possess it with a neutral level. Figure 4 shows that $93 \%$ of employers in the educational workplaces see that the majority of the newly-hired graduates whose performance level is high and satisfactory possess Communicational skills. Surprisingly, the same percentage of employers, $93 \%$, see that EFL teachers whose performance is unsatisfactory lack this skill and only $4 \%$ see that they do.

The contrast shows that desirable EFL teachers have a very high level of communication, while the EFL teachers with unsatisfactory level of communication are not needed in the institution. The matter which highlights the importance of this skill ad tis impact on the evaluation of the EFL teachers' performance level during the COVID-19.

Figure 5 shows that $93 \%$ of employers see that EFL teachers with high performance level possess the skill of SelfManagement or discipline and only $2 \%$ see that they do not. On the other hand, $90 \%$ of the employers find that EFL teachers with unsatisfactory performance evaluation lack this skill and

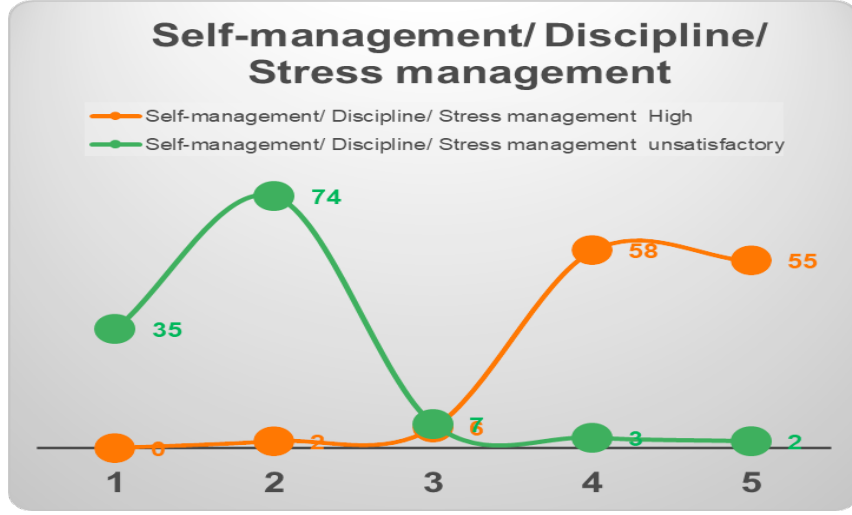

Figure 3. The Degree of Availability of Self-Management in EFL Teachers

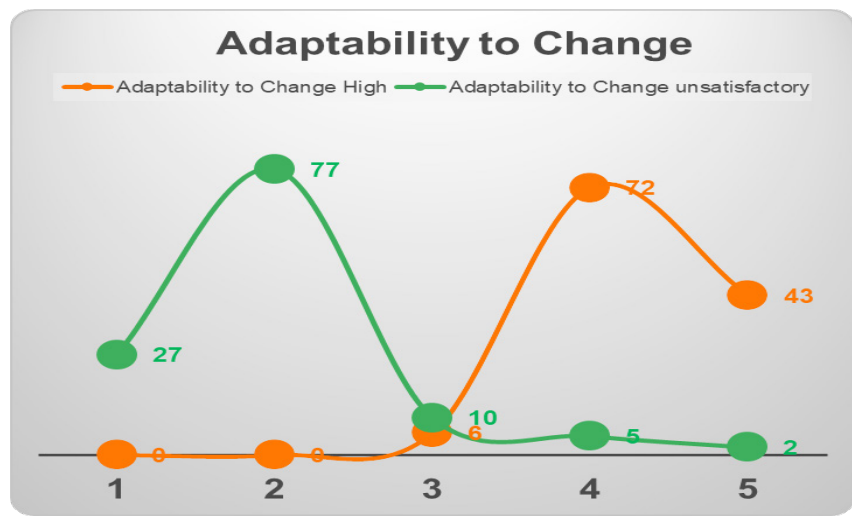

Figure 4: The Degree of Availability of Adaptability to Change in EFL Teachers

only $4 \%$ find that they do. However, these skills vary of their level of importance among the respondents. The majority find it important but not highly demanded in their perspectives since it does not affect the EFL teachers' performance during the COVID-19.

Figure 4 shows that Adaptability to change has been addressed by the majority of respondents as an essential soft skill in the high-performing EFL teachers. 95\% of employers see that EFL teachers whose performance level was satisfactory possess this skill.

The minority considered it less important, however, it is in-demand soft skill that distinguished the EFL teachers whom the institution tend to keep as $86 \%$ of employers see that EFL teachers whose performance is unsatisfactory lack this skill which is considered very important during the COVID-19 crisis and only $6 \%$ of them see that the EFL teachers do.

Figure 5 shows that $87 \%$ of employers see that EFL teachers whose performance evaluation is satisfactory possess this skill while only $2 \%$ see that they do not. Meanwhile, $85 \%$ of the employers see that EFL teachers whose performance level and evaluation is unsatisfactory lack this skill and only $3 \%$ see that they do. 


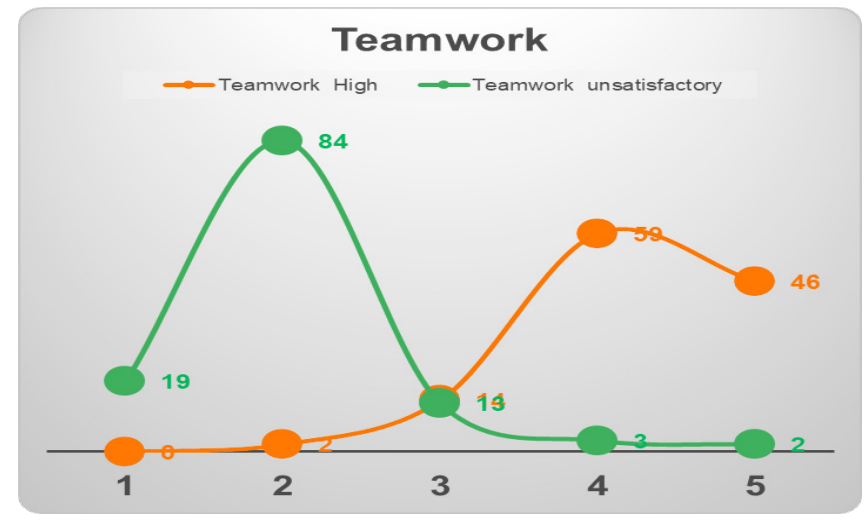

Figure 5. The Degree of Availability of Teamwork in EFL Teachers

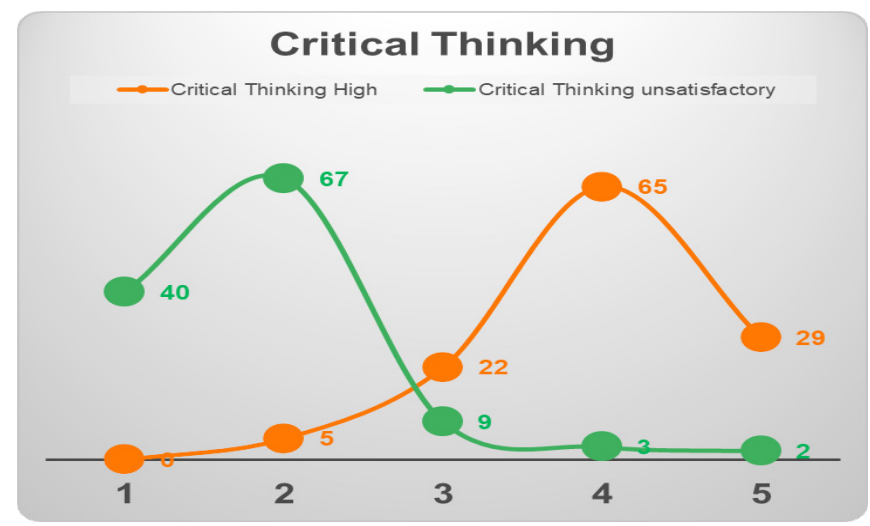

Figure 6. The Degree of Availability of Critical Thinking in EFL Teachers

Despite the importance of Critical thinking as one of the $21^{\text {st }}$ century skills, employers were modest in considering it as an essential skill in their EFL teachers. Figure 6 shows that $78 \%$ of employers see that EFL teachers with high performance level possess this skill and $4 \%$ of them see that those EFL teachers possess this skill with a neutral level. This skill has not affected the performance of the EFL teachers during the COVID-19 and employers highlighted the fact that not all their best EFL teachers possess it. In the contrary, $88 \%$ of employers see that those EFL teachers who have unsatisfactory performance levels possess this skill and only $3 \%$ see that they do not, yet, it does not affect their evaluation.

Figure 7 shows that EFL teachers who have a modest performance evaluation were not necessarily creative. $68 \%$ of employers see that EFL teachers with satisfactory performance level are creative while $2 \%$ see that they are not. On the other hand, $88 \%$ of the employers see that the EFL teachers whose performance level is unsatisfactory are not creative and only $3 \%$ see that they are.

The same pattern applies to innovation, Figure 8 shows that $60 \%$ of employers see that the EFL teachers with satisfactory performance levels are innovative. Meanwhile, $86 \%$ of

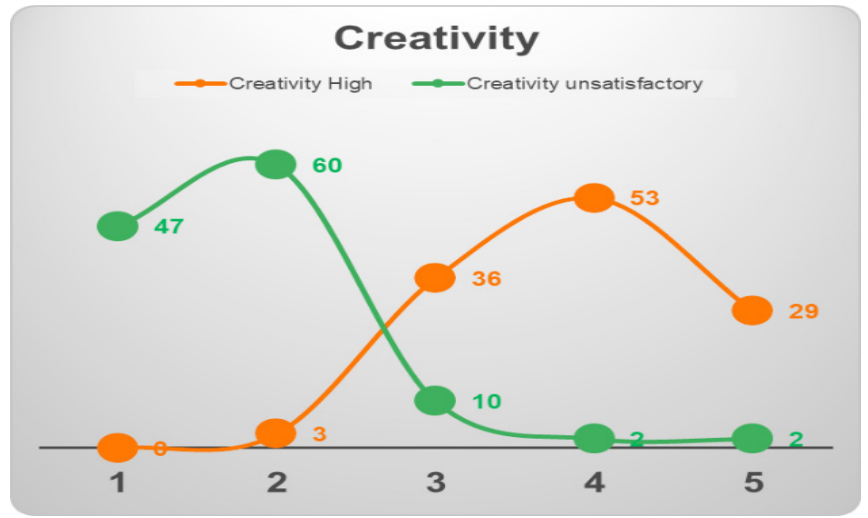

Figure 7: The Degree of Availability of Creativity in EFL Teachers

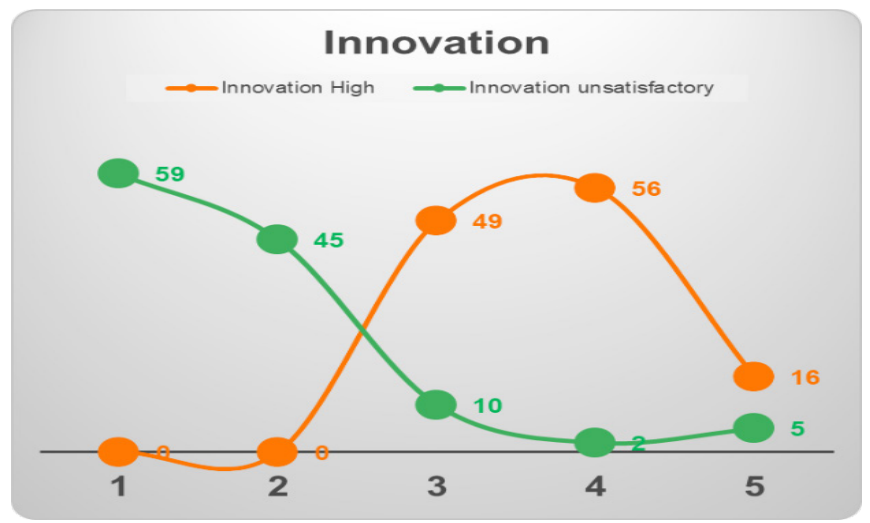

Figure 8. The Degree of Availability of Innovation in EFL Teachers

the employers see that EFL teachers whose performance is unsatisfactory are not innovative and only $6 \%$ see that they are. Surprisingly, the percentages suggest that employers did not connect creativity and innovation as essential factors in the EFL teachers' performance during the COVID-19. Innovation, is usually combined with creativity, thus, the skill is not given a high focus when evaluating the performance of the best and the less favored EFL teachers. The contrast in the two lines shows that this skill does not affect the employer's decisions about renewing the EFL teachers' contracts, neither is the case with creativity.

Despite the great importance of flexibility during tough times like the COVID-19 crisis, Figure 9 shows that Flexibility has been given a neutral level of importance in the performance evaluation of EFL teachers in the educational field. $83 \%$ $s$ of respondents see that EFL teachers with satisfactory performance level possess this skill and only $2 \%$ see that they do not. Meanwhile, $85 \%$ see that EFL teachers whose performance is unsatisfactory lack Flexibility and only $5 \%$ of them see that they do.

Employers in the educational places do not consider it in the top requirement for keeping their best employers nor based 


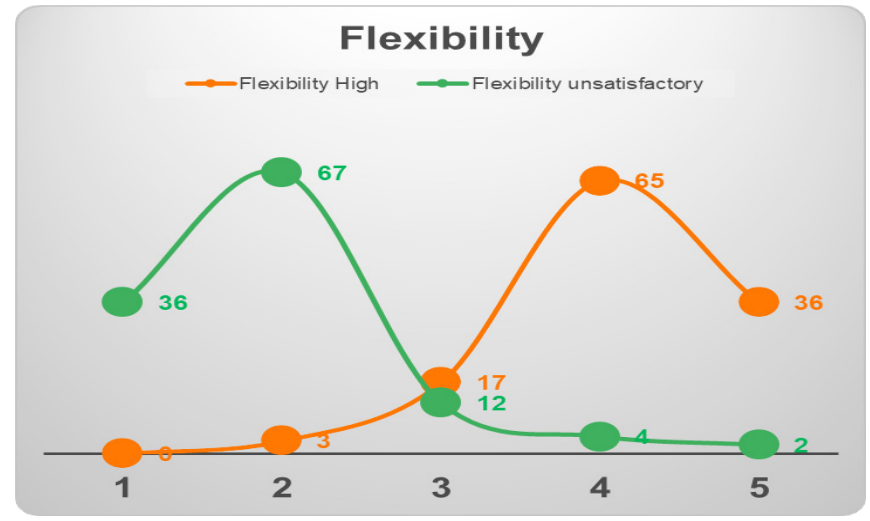

Figure 9. The Degree of Availability of Flexibility in EFL Teachers

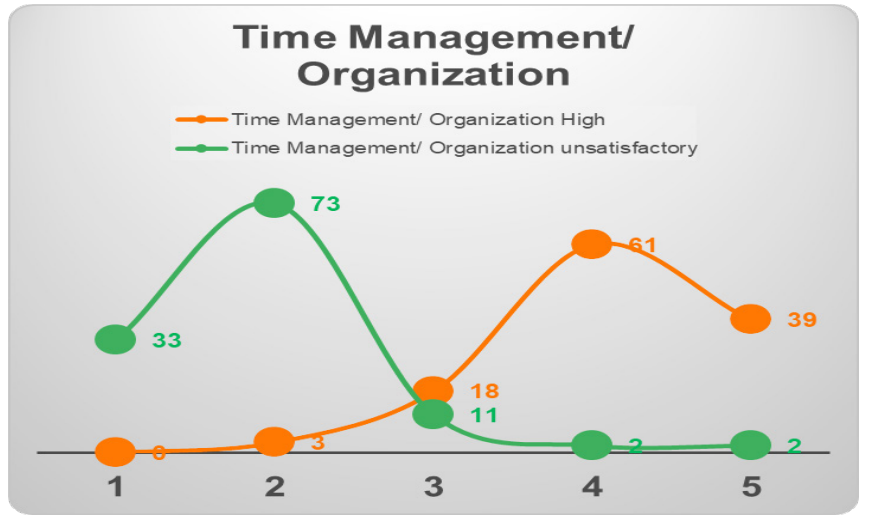

Figure 10. The Degree of Availability of Time Management in EFL Teachers

Table 2: The Finding of the Significant Statistical Differences in the Degree of Soft Skills Acquisition Attributed to the Performance Level of the EFL Teachers

\begin{tabular}{|c|c|c|c|c|c|}
\hline Soft Skill in-Demand & Performance & $N$ & Mean & Std. Deviation & Std. Error Mean \\
\hline \multirow[t]{2}{*}{ Being professionally ethical } & High Performance & 121 & 4.8678 & .64475 & .05861 \\
\hline & Unsatisfactory Performance & 121 & 1.8843 & .88685 & .08062 \\
\hline \multirow[t]{2}{*}{ Communication } & High Performance & 121 & 4.3967 & 61209 & .05564 \\
\hline & Unsatisfactory Performance & 121 & 1.9008 & .74616 & .06783 \\
\hline \multirow{2}{*}{$\begin{array}{l}\text { Self-management/ Discipline/ } \\
\text { Stress management }\end{array}$} & High Performance & 121 & 4.3719 & .65995 & .06000 \\
\hline & Unsatisfactory Performance & 121 & 1.8678 & .76313 & .06938 \\
\hline \multirow[t]{2}{*}{ Adaptability to Change } & High Performance & 121 & 4.3058 & .56040 & .05095 \\
\hline & Unsatisfactory Performance & 121 & 1.9917 & .79053 & .07187 \\
\hline \multirow[t]{2}{*}{ Teamwork } & High Performance & 121 & 4.2314 & .71601 & .06509 \\
\hline & Unsatisfactory Performance & 121 & 2.0496 & .71707 & .06519 \\
\hline \multirow[t]{2}{*}{ Critical Thinking } & High Performance & 121 & 3.9752 & .76880 & .06989 \\
\hline & Unsatisfactory Performance & 121 & 1.8430 & .79591 & .07236 \\
\hline \multirow[t]{2}{*}{ Creativity } & High Performance & 121 & 3.8926 & .79374 & .07216 \\
\hline & Unsatisfactory Performance & 121 & 1.7769 & .80091 & .07281 \\
\hline \multirow[t]{2}{*}{ Innovation } & High Performance & 121 & 3.7273 & .68313 & .06210 \\
\hline & Unsatisfactory Performance & 121 & 1.7521 & .97708 & .08883 \\
\hline \multirow{2}{*}{$\begin{array}{l}\text { Time Management/ } \\
\text { Organization }\end{array}$} & High Performance & 121 & 4.1240 & .74800 & .06800 \\
\hline & Unsatisfactory Performance & 121 & 1.9008 & .75724 & .06884 \\
\hline \multirow[t]{2}{*}{ Flexibility } & High Performance & 121 & 4.1074 & .72803 & .06618 \\
\hline & Unsatisfactory Performance & 121 & 1.9174 & .82246 & .07477 \\
\hline
\end{tabular}

their decisions about terminating the contracts for those who do not show an acquisition of that skill. $23 \%$ of the employers see that both EFL teachers with the satisfactory performance level and those with unsatisfactory ones possess this skill with a neutral percentage.

Figure 10 shows that $83 \%$ of employers in the educational workplaces see that EFL teachers with high performance possess the skill of time management and organization and only $2 \%$ see that these EFL teachers lack this skill. the majority of respondents highlighted the importance of implementing
Time management and organization during the COVID-19. EFL teachers who have a good performance evaluation were the ones who could reflect high levels of time management and organization at their work. On the other hand, $88 \%$ see that EFL teachers with unsatisfactory performance levels lack this skill and only $3 \%$ of them see that they possess it.

It is noticed in table 2 that there is a difference in the acquisition degree of Being professionally ethical between EFL teachers with satisfactory performance degree and those with unsatisfactory performance degree. From employers' 
perspective, the average of the degree of acquisition of this particular skill in EFL teachers with satisfactory performance was 4.87 while the average of the degree of acquisition in those with unsatisfactory performance was 1.88 . This difference emerged with all other soft skills listed by the employers in the educational field.

When addressing Communication, the average of the degree of acquisition among the EFL teachers with satisfactory performance degree was 4.49 while the average of the degree of acquisition of this skill in EFL teachers with unsatisfactory performance level was 1.90 . The same pattern was repeated in the skills of Self-Management, with a difference of 4.47 among the EFL teachers with the satisfactory performance and 1.97 among the ones with the unsatisfactory performance level and almost the same difference degree was found with Adaptability to change; 4.30-1.99, Time management; 4.121.90, and Flexibility; 4.10-1.91.

As for skills like Teamwork, Critical Thinking, and Innovation, the difference was not big. The average of the degree of acquisition among EFL teachers with satisfactory performance level was 4.23 , while the average of the degree of acquisition among the EFL teachers with unsatisfactory performance level was 2.04. The same pattern is repeated in the skills of Critical Thinking; 3.97-1.84, Creativity and Innovation with almost the same average of 3.99 among EFL teachers with satisfactory performance level and 1.87 among those of unsatisfactory performance level.

In order to study the substantial difference between the averages of the degree of skill acquisition in accordance to the level of performance, a T-test has been conducted to measure the effect of the level of performance on the degree of the skills acquisition, as shown in Table 2.

Table 3 shows that there is a statistical effect or a statistical indication of the EFL teachers'performance level on the degree of the skill of Being professionally ethical and for the benefit of EFL teachers with satisfactory performance level, as the value of T-test 29.931 with a level of significance of $(\alpha=0.000)$. Moreover, there is a statistical difference between the averages of the degree of acquisition of Communication skills due to the level of performance for the benefit of the EFL teachers with satisfactory performance where the value of T-test is 28.45 .

Meanwhile, the same difference appears with skills like Self-management where T-test is 27.37, Adaptability to change with an average of 26.37, Teamwork where T-test is 23.79,

Table 3.: Leven's Test for Equality of Variances

\begin{tabular}{|c|c|c|c|c|c|c|c|c|}
\hline & & & & & & & T-test for $\mathrm{E}$ & ty of Means \\
\hline & & $F$ & Sig. & $t$ & $d f$ & $\begin{array}{l}\text { Sig } \\
\text { (2 tailed) }\end{array}$ & $\begin{array}{l}\text { Mean } \\
\text { difference }\end{array}$ & $\begin{array}{l}\text { Std.error } \\
\text { difference }\end{array}$ \\
\hline \multirow[t]{2}{*}{ Being professionally ethical } & Equal variances assumed & 25.991 & .000 & 29.931 & 240 & .000 & 2.98347 & .09968 \\
\hline & Equal variances not assumed & & & 29.931 & 219.152 & .000 & 2.98347 & .09968 \\
\hline \multirow[t]{2}{*}{ Communication } & Equal variances assumed & 4.523 & .034 & 28.448 & 240 & .000 & 2.49587 & .08774 \\
\hline & Equal variances not assumed & & & 28.448 & 231.164 & .000 & 2.49587 & .08774 \\
\hline \multirow{2}{*}{$\begin{array}{l}\text { Self-management/ Discipline/ } \\
\text { Stress management }\end{array}$} & Equal variances assumed & 1.324 & .251 & 27.302 & 240 & .000 & 2.50413 & .0172 \\
\hline & Equal variances not assumed & & & 27.302 & 235.08 & .000 & 2.50413 & .0172 \\
\hline \multirow{2}{*}{ Adaptability to Change } & Equal variances assumed & .630 & .428 & 26.269 & 240 & .000 & 2.31405 & .08809 \\
\hline & Equal variances not assumed & & & 26.269 & 216.291 & .000 & 2.31405 & .08809 \\
\hline \multirow[t]{2}{*}{ Teamwork } & Equal variances assumed & 8.006 & .005 & 23.684 & 240 & .000 & 2.18182 & .09212 \\
\hline & Equal variances not assumed & & & 23.684 & 239.999 & .000 & 2.18182 & .09212 \\
\hline \multirow[t]{2}{*}{ Critical Thinking } & Equal variances assumed & .294 & .588 & 21.196 & 240 & .000 & 2.13223 & .10060 \\
\hline & Equal variances not assumed & & & 21.196 & 239.712 & .000 & 2.13223 & .10060 \\
\hline \multirow[t]{2}{*}{ Creativity } & Equal variances assumed & .109 & .742 & 20.639 & 240 & .000 & 2.11570 & .10251 \\
\hline & Equal variances not assumed & & & 20.639 & 239.981 & .000 & 2.11570 & .10251 \\
\hline \multirow[t]{2}{*}{ Innovation } & Equal variances assumed & 4.768 & .030 & 18.224 & 240 & .000 & 1.97521 & .10838 \\
\hline & Equal variances not assumed & & & 18.224 & 214.691 & .000 & 1.97521 & .10838 \\
\hline \multirow{2}{*}{$\begin{array}{l}\text { Time Ma nage me } \mathrm{nt} / \\
\text { Organization }\end{array}$} & Equal variances assumed & 1.146 & .285 & 22.975 & 240 & .000 & 2.22314 & .09676 \\
\hline & Equal variances not assumed & & & 22.975 & 239.964 & .000 & 2.22314 & .09676 \\
\hline \multirow[t]{2}{*}{ Flexibility } & Equal variances assumed & .042 & .837 & 21.933 & 240 & .000 & 2.19008 & .09985 \\
\hline & Equal variances not assumed & & & 21.933 & 236.516 & .000 & 2.19008 & .09985 \\
\hline
\end{tabular}


Critical thinking where T-test is 21.196 which is close to the result in creativity where T-test is 21 . Also, Time management and Flexibility showed almost the same statistical differences where T-test is almost 22 in both.

\section{Discussion}

The implications of such results urge educational institutions to focus on improving certain skills that graduates lack such as Flexibility and Critical thinking. It is mere an opinion that creativity cannot always be acquired but it is a natural talent that many people lack because they were not born with this skill. Some arguments are in favor of the idea that skills like Innovation and Creativity are meant to exist by the person's nature and cannot be developed.

Another point to be considered is that the acquisition process of these competencies is a dynamic one through which soft skills evolve and develop gradually by time and by involving in the practical field (Cimatti, 2016). Therefore, it can be acceptable to some extent for graduates to lack certain skills due to the lack of implementation and application of these skills during the studying period of time.

It is worth to emphasize that soft skills modify and complement hard skills, which are connected to the practical implementation of knowledge in the practical field. Success in this case is a combination of two main factors; the technical knowledge or the hard skill which is measurable and evaluated by observing the performance while the other factor comprises the soft skills which contribute to the success of delivering knowledge (Singh et al., 2014).

Thus, the relationship between the two sets of skills is a positive correlation and each one is influenced by the other. It is obviously presented in this study that acquisition of soft skills is positively reflected in the performance and vice versa. EFL teachers with high level of performance have shown excellent levels of soft skills acquisitions, especially to skills that are highly ranked by employers such as Being professionally ethical, Teamwork and Communication in particular for its importance and vital role in enhancing the speaking skill, thus, effective language practice (Robertson, 2021).

Employers, are not interested in renewing contracts with those who lack the previous skills in the educational workplaces, the matter which reflects the importance of these skills during the COVID-19 era. Other skills such as Creativity, Innovation and Flexibility are naturally preferable and both EFL teachers of satisfactory and unsatisfactory performance level possessed them with a neutral level without affecting their employability status from their employers' perspectives (Succi \& Canovi, 2020).

The recent drastic changes in the educational workplaces have placed this field under pressure to choose and keep the best EFL teachers. In order to achieve this, training programs and university qualifications should be developed to implement soft skills effectively in education as acquisition and practice. Moreover, there should be sustainable update of the set of soft skills implemented to ensure compliance with the requirement of the era (Cacciolatti et al., 2017). For example, digital literacy and global awareness and considered as novel skills that have been prioritized currently due to globalization and to the world pandemic.

It is evident that most educational institutions select and recruit the human resources with the best soft skills available. The current markets and workplaces that were changed by the impact of the COVID-19 foster the development of skills more than cognitive knowledge (Cimatti, 2016).

\section{Conclusion}

The degree of soft skills acquisition by the newly-hired graduates in the educational workplaces from the employers' perspectives varies between strong availability of skills like Communication and Time management. Meanwhile, it is available in skills like Self-management, Teamwork and Innovation. On the other hand, Being professionally ethical, Adaptability to change, Critical thinking, and Flexibility are neutrally available or available to a humble degree. As for Creativity, most EFL teachers lack this skill in particular from employers' perspectives.

The relationship between the level of performance among the newly-hired graduates and the acquisition of the in-demand soft skills is positive. The employers whose perspectives are the base of the answers, find that the acquisition of some skills is affected by the level of the EFL teachers' performance. EFL teachers with high and satisfactory performance levels are the ones who possess important in-demand soft skills, such as Being professionally ethical, Communication, and Teamwork.

There is a substantial impact of the EFL teachers' performance levels; satisfactory and unsatisfactory, on the degree of the in-demand soft skills acquisition.

The significant statistical differences in the degree of soft skills acquisition are attributed to the performance level of the newly hired graduate, the T-test results showed a positive correlation regarding the existence of the difference. The statistical differences indicate that EFL teachers with satisfactory performance levels possess soft skills in higher levels than those whose performance levels are unsatisfactory.

The positive correlation between the EFL teachers' performance level and the in-demand soft skills acquisition is eminent. Employers highlighted that the focus on skills like Being professionally ethical, Teamwork, Communication and Adaptability to change enhanced EFL teachers' performance during the lockdown imposed by the COVID-19.

\section{Recommendations}

Designing a consistent soft-skills acquisition training program for university students is recommended in a step 
towards maintaining a smooth transition into the practical field.

In addition, this report recommends further work to:

- Make regular assessments to newly-hired graduates based on their soft skills and their performance in the field.

- Develop training programs for EFL teachers based on the in-demand soft skills.

- Research further the novel soft skills that might be in demand in the future.

- Implement soft skills acquisition in schools' curriculums and educational programs.

- Focus on soft skills in job announcements and giving them the same importance as the academic qualifications and the cognitive skills.

- Develop and abide by the "Soft Skills Matrix", in Figure 11, to tackle EFL teachers needs and build training programs based on its findings. The matrix can contribute to the EFL teachers themselves by giving them feedback about the status of their acquisition to the in-demand soft skills in the educational workplaces. It also gives employers an eminent image about the progress of EFL teachers in acquiring and implementing soft skills, thus, assessing and evaluating the performance of these EFL teachers based on the data given by this matrix.

\section{LIMITATIONS}

The study will be conducted on the employers and employees in the educational workplaces of the private sector; private schools in addition to the EFL teachers who are working

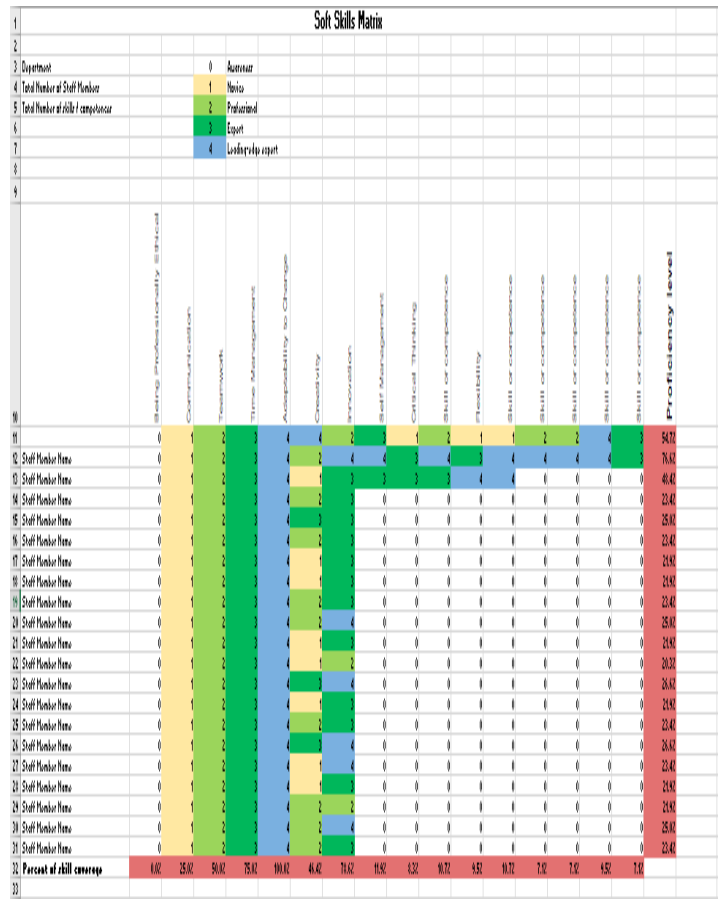

Figure 11: Soft Skills Matrix in private schools. The study will be conducted on the Soft skills demanded by employers in the educational workplaces during and post COVID 19 in addition to the soft skills that are acquired by the EFL teachers and the relationship between the existence of the soft skills already acquired and the performance of the EFL teachers 'performance.

\section{Acknowledgements}

The authors are grateful to the Middle East University, Amman, Jordan, for the financial support granted to cover this research article's publication fee.

\section{References}

Asif, M., Zhiyong, D., Raisinghani, M. S., \& Hassan, A. (2021). Rhetoric Situation of Novel Coronavirus (COVID-19) in Social Media and its Impact on Pedagogy. International Journal of Online Pedagogy and Course Design (IJOPCD), 11(3), 62-77. http://doi.org/10.4018/IJOPCD.2021070105

Buheji, M., \& Buheji, A. (2020). Planning Competency in the New Normal- Employability Competency in Post- COVID-19 Pandemic. International Journal of Human Resource Studies, 10(2), 237. https://doi.org/10.5296/ijhrs.v10i2.17085

Cacciolatti, L., Lee, S. H., \& Molinero, C. M. (2017). Clashing institutional interests in skills between government and industry: An analysis of demand for technical and soft skills of graduates in the UK. Technological Forecasting and Social Change, 119, 139-153. https://doi.org/10.1016/j. techfore.2017.03.024

Cimatti, B. (2016). Definition, development, assessment of soft skills, and their role for the quality of organizations and enterprises. International Journal for Quality Research, 10(1), 97-130. https://doi.org/10.18421/IJQR10.01-05

Cornali, F. (2018). Training and developing soft skills in higher education. 961-967. https://doi.org/10.4995/head18.2018.8127

Editor, C., \& Medriano, R. (2021). Tesol international journal. 16(4).

Fixsen, A., \& Ridge, D. (2019). Shades of Communitas: A Study of Soft Skills Programs. Journal of Contemporary Ethnography, 48(4), 510-537. https://doi.org/10.1177/0891241618792075

Garcia, E. (2014). The Need To Address No cognitive Skills in the Education Policy. Economic Policy Institute Briefing Paper \#386, 1-36. Retrieved from www.epi.org, May 1, 2015

Immanuel, G., Sankar, G., Saravanan, V., \& Jose, M. (2021). Materials Today : Proceedings Significance of interpersonal skills and english language teaching. $\mathrm{xxxx}$.

Jaser Khalaf Mahasneh. (2016). A Theoretical Framework for Implementing Soft Skills in Construction Education Utilizing Design for Six Sigma. https://pdfs.semanticscholar.org/0670/3 c706beb903185969b2cb41a7aaeb5c1054a.pdf

Mishra, D. L., Gupta, D. T., \& Shree, D. A. (2020). Online Teaching-Learning in Higher Education during Lockdown Period of COVID-19 Pandemic. International Journal of Educational Research Open, 100012. https://doi.org/10.1016/j. ijedro.2020.100012

Patel, P. C., \& Rietveld, C. A. (2020). The impact of financial insecurity on the self-employed's short-term psychological distress: Evidence from the COVID-19 pandemic. Journal of 
Business Venturing Insights, 14(August), e00206. https://doi. org/10.1016/j.jbvi.2020.e00206

Pisoni, G., Gaio, L., \& Rossi, A. (2019). Investigating Soft Skills Development through Peer Reviews Assessments in an Entrepreneurship Course. Proceedings - 2019 IEEE International Symposium on Multimedia, ISM 2019, 291-296. https://doi. org/10.1109/ISM46123.2019.00065

Robertson, P., \& Adamson, J. (2020). The Asian EFL Journal January 2020 Volume 24 Issue 1. 24(1).

Robertson, P. (2021). Asian EFL Journal, Asian EFL Journal Volume 28 Issue 2.2 April 2021.

Singh Dubey, R., \& Tiwari, V. (2020). Operationalization of soft skill attributes and determining the existing gap in novice
ICT professionals. International Journal of Information Management, 50(September 2019), 375-386. https://doi. org/10.1016/j.ijinfomgt.2019.09.006

Succi, C., \& Canovi, M. (2020). Soft skills to enhance graduate employability: comparing students' and employers' perceptions. Studies in Higher Education, 45(9), 1834-1847. https://doi.org/1 0.1080/03075079.2019.1585420

Tseng, H., Yi, X., \& Yeh, H. Te. (2019). Learning-related soft skills among online business students in higher education: Grade level and managerial role differences in self-regulation, motivation, and social skill. In Computers in Human Behavior (Vol. 95). Elsevier B.V. https://doi.org/10.1016/j.chb.2018. 11.035 